\title{
Tree density and species decline in the African Sahel attributable to climate
}

\author{
P. Gonzalez ${ }^{\mathrm{a}, *}$, C.J. Tucker ${ }^{\mathrm{b}}$, H. Sy ${ }^{\mathrm{c}}$ \\ ${ }^{a}$ Center for Forestry, University of California, Berkeley, 163 Mulford, Berkeley, CA 94720-3114, USA \\ b Goddard Space Flight Center, National Aeronautics and Space Administration, Greenbelt, MD 20771, USA \\ ${ }^{c}$ Réseau de Systèmes d'Alerte Précoce contre la Famine (Famine Early Warning Systems Network), B.P 222, Nouakchott, Mauritanie
}

\section{A R T I C L E I N F O}

\section{Article history:}

Received 8 October 2010

Received in revised form

20 October 2011

Accepted 1 November 2011

Available online 17 November 2011

\section{Keywords:}

Climate change

Climate variability

Desertification

Tree cover

Vegetation shifts

\begin{abstract}
A B S T R A C T
Increased aridity and human population have reduced tree cover in parts of the African Sahel and degraded resources for local people. Yet, tree cover trends and the relative importance of climate and population remain unresolved. From field measurements, aerial photos, and Ikonos satellite images, we detected significant 1954-2002 tree density declines in the western Sahel of $18 \pm 14 \%(P=0.014$, $n=204)$ and $17 \pm 13 \%(P=0.0009, n=187)$. From field observations, we detected a significant $1960-$ 2000 species richness decline of $21 \pm 11 \%(P=0.0028, n=14)$ across the Sahel and a southward shift of the Sahel, Sudan, and Guinea zones. Multivariate analyses of climate, soil, and population showed that temperature most significantly $(P<0.001)$ explained tree cover changes. Multivariate and bivariate tests and field observations indicated the dominance of temperature and precipitation, supporting attribution of tree cover changes to climate variability. Climate change forcing of Sahel climate variability, particularly the significant $(P<0.05)$ 1901-2002 temperature increases and precipitation decreases in the research areas, connects Sahel tree cover changes to global climate change. This suggests roles for global action and local adaptation to address ecological change in the Sahel.
\end{abstract}

() 2011 Elsevier Ltd. All rights reserved.

\section{Introduction}

In the African Sahel, people depend on trees for wood, shade, protection of soil fertility, and other natural resources and services. In the 20th century, rainfall in the Sahel declined 20-30\% (Hulme et al., 2001; Dai et al., 2004), the most negative rainfall trend in the world in the instrumental record (Trenberth et al., 2007), and mean temperature increased up to $1.3{ }^{\circ} \mathrm{C}$ (Hulme et al., 2001; Trenberth et al., 2007). As a result, aridity in the Sahel increased, degrading tree cover in many areas (Poupon, 1980; Gonzalez, 2001; Wezel and Lykke, 2006; Maranz, 2009) and leading to the death of a quarter million people in a 1968-1972 drought (U.S. Centers for Disease Control, 1973). This prompted countries to adopt, in 1994, the United Nations Convention to Combat Desertification.

The rainfall decline and temperature increase comprise the two principal forms of 20th century Sahel climate variability. Increasing sea surface temperature governs the decline in rainfall (Giannini et al., 2003; Held et al., 2005; Hegerl et al., 2007; Shanahan et al., 2009), while reduction of vegetation cover amplifies the decline through positive feedbacks between precipitation and vegetation via reduced evapotranspiration (Zeng et al., 1999) and increased

\footnotetext{
* Corresponding author.

E-mail address: pgonzalez@cal.berkeley.edu (P. Gonzalez).
}

albedo (Charney, 1975). Although lake sediment data indicate that the recent Sahel drought falls within the magnitude of West African droughts during the past 2500 years (Shanahan et al., 2009), increased atmospheric concentrations of greenhouse gases during the 20th century have increased sea surface temperatures, leading to the recent reduction in Sahel rainfall (Held et al., 2005; Zhang et al., 2007). Increased atmospheric concentrations of greenhouse gases have increased land temperatures globally, including in the Sahel (Hegerl et al., 2007). Thus, instrumental measurements and computer modeling attribute the two principal forms of 20th century Sahel climate variability to anthropogenic climate change (Wang and Eltahir, 2002; Held et al., 2005; Biasutti and Giannini, 2006; Hegerl et al., 2007; Zhang et al., 2007).

In West and Central Africa, increasing rainfall toward the Equator (Fig. 1a) and decreasing temperature toward the coasts (Fig. 1b) increase vegetation productivity (Fig. 1c) and differentiate vegetation into three latitudinal ecological zones of increasingly mesic tree species and increasing biodiversity: the Sahel, the Sudan, and Guinea (Aubréville, 1950) (Fig. 1d). The Sahel, the Sudan, and Guinea are biome-level zones of, respectively, savanna with shrubs and thorny tree species with bipinnately compound leaves, tropical woodland of trees with pinnately compound leaves and dry fruits, and tropical deciduous broadleaf closed-canopy forest of trees with simple broad leaves and moist fruit. In the Sahel and Sudan, individual woody plants of the same species grow in a continuum of 

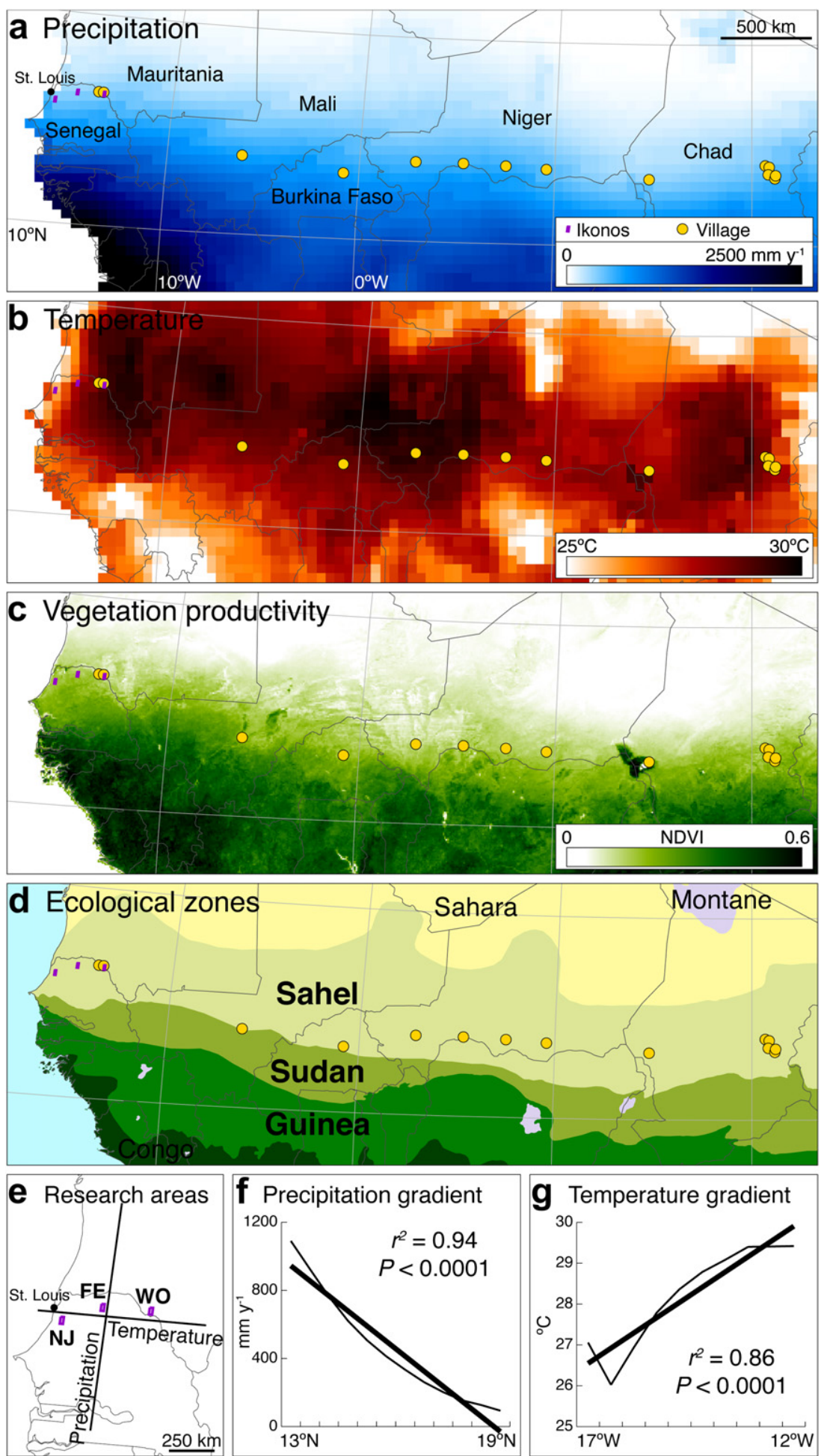

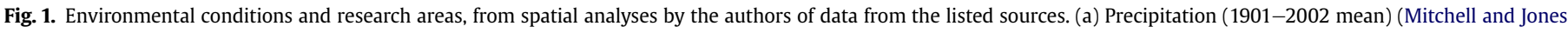

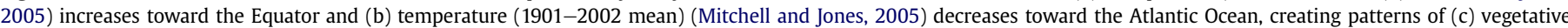

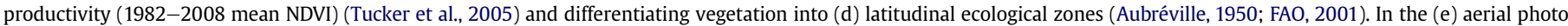

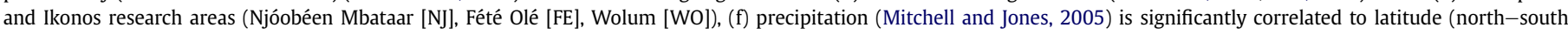

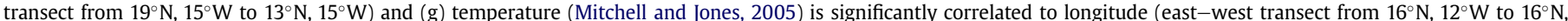
$\left.17^{\circ} \mathrm{W}\right)$.

forms ranging from short multi-stemmed plants with a low crown (shrubs) to plants with a single trunk and elevated crown (trees). For brevity, trees and shrubs are hereafter referred to as trees.

Field research across the Sahel has documented decreases in tree density and changes in tree species richness in the last half of the 20th century that were not directly caused by local people. Tree density declined at sites in Senegal (Poupon, 1980; Gonzalez, 2001; Vincke et al., 2010) while arid species expanded and mesic species declined in Burkina Faso (Rasmussen et al., 2001; Wezel and Lykke, 2006; Maranz, 2009), Niger (Wezel and Lykke, 2006), and Senegal 
(Gonzalez, 2001; Wezel and Lykke, 2006; Vincke et al., 2010). On the other hand, research showed no decrease in tree density at sites in Burkina Faso (Rasmussen et al., 2001), Mali (Hiernaux et al., 2009), and the Republic of the Sudan (Schlesinger and Gramenopoulos, 1996). Agricultural expansion and livestock grazing, not climate, reduced tree density at sites in Mauritania (Niang et al., 2008) and Senegal (Lericollais, 1989). Recent natural regeneration by farmers increased tree density at a site in Burkina Faso (Reij et al., 2005).

Some studies have attempted to assess Sahel vegetation cover trends using the normalized difference vegetation index (NDVI; Tucker, 1979), derived from the Advanced Very High Resolution Radiometer sensor of the National Oceanic and Atmospheric Administration polar-orbiting meteorological satellite series (e.g. Anyamba and Tucker, 2005; Seaquist et al., 2006). Others have used rain-use efficiency (RUE; Le Houérou, 1984), calculated using NDVI (e.g. Nicholson et al., 1998; Prince et al., 1998; Hein et al., 2011).

Two characteristics of the NDVI data series constrain the interpretation of results of those studies. First, NDVI in the Sahel mainly tracks interannual variability of herbaceous vegetation. NDVI is an index of the fraction of photosynthetically active radiation absorbed by plants, which is proportional to green leaf area. In the Sahel, green leaf area of the herbaceous layer, composed mainly of annual grasses, substantially exceeds the green leaf area of trees and shrubs, which allocate a higher fraction of biomass to wood, undetected by NDVI. Second, annual NDVI coverage began in 1982. A drought in the Sahel from 1982 to 1984 and a slight increase of rainfall in the 1980s and 1990s led to short-term increases in NDVI (Anyamba and Tucker, 2005; Seaquist et al., 2006) and RUE (Nicholson et al., 1998; Prince et al., 1998) in some areas, showing possible increases in vegetation cover (Olsson et al., 2005). Because of the particular characteristics of the NDVI data series, however, NDVI can only show that herbaceous vegetation increased and only after 1982.

In contrast, tree density and biodiversity indicate trends of vegetation cover over longer time periods than NDVI because trees often withstand years of stress before dying (Allen et al., 2010). Furthermore, changes in tree species composition can reveal changes in environmental factors even if total tree density does not change. Aerial photographs and high-resolution satellite images can provide data on tree densities. Structured surveys of traditional knowledge and field surveys can provide data on past and current tree species distributions.

The decline in rainfall and rise in temperature in the Sahel occurred at approximately the same time as a substantial increase in population. Population in the Sahel grew during the 20th century, and, from 1960 to 1995, increased from 21 million people to 46 million in the nine Sahel countries of Central and West Africa (OECD , 1998). The increases in aridity and population have exerted pressure on tree cover in the Sahel, although the relative importance of these two factors remains unresolved. Improved knowledge of vegetation change in the Sahel could increase the effectiveness of programs to address the vulnerability of people and management of natural resources in the region. We investigated these issues with two research objectives: (1) to detect long-term changes in the density and species richness of trees and shrubs in the Sahel and (2) to attribute causes of detected changes.

\section{Materials and methods}

\subsection{Research areas for tree density}

We quantified tree density in three research areas in the western Sahel (Fig. 1e), where precipitation shows a significant latitudinal gradient (Fig. 1f) and temperature shows a significant longitudinal gradient (Fig. 1g). Each area is a $10 \mathrm{~km}$ (east-west) by $20 \mathrm{~km}$ (north-south) rectangle. The research areas (and center latitude and longitude) are: Njóobéen Mbataar, Senegal $\left(15.80^{\circ} \mathrm{N}\right.$, $\left.16.25^{\circ} \mathrm{W}\right)$, Fété Olé, Senegal $\left(16.23^{\circ} \mathrm{N}, 15.10^{\circ} \mathrm{W}\right)$, and Wolum, Mauritania $\left(16.25^{\circ} \mathrm{N}, 13.67^{\circ} \mathrm{W}\right)$. They are spaced at $\sim 150 \mathrm{~km}$ along approximately the same latitude. Past research examined trees and shrubs at Njóobéen Mbataar (Gonzalez, 2001) and Fété Olé (Poupon, 1980). The Njóobéen Mbataar area consists of agricultural fields with trees, interspersed with shrubland and woodland, inhabited by the Wolof ethnic group. The Fété Olé area consists of grassland used by the Fulbe ethnic group for grazing livestock, interspersed with shrubland and woodland. The Wolum area consists of grassland with single shrubs and trees, used by the Hal Pulaar-en ethnic group for grazing livestock. Although some farmers use low-intensity fires to clear fields of weeds before planting, wildfires are not as common as in areas to the south and result mainly from anthropogenic, not natural, ignition (Poupon, 1980).

\subsection{Research village areas for tree species richness}

We quantified tree species richness in 14 village areas in five countries, sampling much of the longitudinal extent of the Sahel (Fig. 1a-d). During field trips to rural areas, local staff of the Réseau de Systèmes d'Alerte Précoce contre la Famine (Famine Early Warning Systems Network) selected villages not previously known to them or the authors. We sought rural villages that met the following criteria: medium population ( $150-300$ people), agriculture or livestock herding as the predominant occupation, minimal urban infrastructure, absence of deep-bore wells that would attract large herds of livestock that could alter vegetation (Vincke et al., 2010), and presence of elder residents with detailed knowledge of natural history.

\subsection{Field measurements of trees}

To characterize the trees and shrubs of the three research areas and calibrate remote sensing data to field observations, we delineated 12 1-ha square quadrats located at the centers of the four quarters (NW, NE, SE, SW) of each research area. In May 2002, we identified the species (Table A1) and counted all live and dead trees and shrubs in the quadrats. We measured all tree and shrub heights (h), diameter at breast height $(h=1.3 \mathrm{~m})$, diameter at $h=40 \mathrm{~cm}$, diameter at ground level (shrubs and trees of $h \leq 40 \mathrm{~cm}$ ), and number of branches. In November 2005, we re-inventoried the Njóobéen Mbataar NW quadrat. We created geographic information system (GIS) point files of field tree locations.

\subsection{Tree density}

We determined current and past tree densities from Ikonos satellite images and historical aerial photographs, respectively, calibrated and validated by the field measurements of trees. The Ikonos satellite acquired cloud-free scenes of the Njóobéen Mbataar (11:56 AM UTC, February 17, 2002), Fété Olé (11:38 AM UTC, February 22, 2002), and Wolum (11:37 AM UTC, February 22, 2002) research areas from a sun-synchronous orbital altitude of $680 \mathrm{~km}$. We timed acquisition to match the months of historical aerial photo missions. February is the middle of the dry season in the Sahel, providing high contrast of trees over bare ground. Ikonos captured one band of panchromatic data at $1 \mathrm{~m}$ spatial resolution and four bands of multi-spectral data at $4 \mathrm{~m}$ spatial resolution, with each band as a GeoTiff file at 11 bit data depth. Space Imaging, Inc. provided geometrically corrected Ikonos data with a horizontal accuracy (root mean square error) of $8 \mathrm{~m}$. We used the 
panchromatic band, setting display histograms to view the images with approximately the same brightness and contrast observed in the field.

We acquired 31 aerial photos on paper: Njóobéen Mbataar, February 1954, Mission AOF 083 ND-28-XX 1954 (9 photos); Fété Olé, February-April 1954, Mission AOF 088 NE-28-III 1954 (8 photos); Wolum, February-April 1954, Mission AOF 090 NE28-V 1954 (8 photos); from the Institut Géographique National (IGN), France at 1: 50,000 scale; and Njóobéen Mbataar, March 1989, Japan International Cooperation Agency (JICA) Mission 1989 (6 photos), from the Service Géographique National, Senegal at 1: 60,000 scale. We scanned the IGN photos at 500 dots $\mathrm{cm}^{-1}$ and the JICA photos at 600 dots $\mathrm{cm}^{-1}$ to produce 8 bit tiff images of $1 \mathrm{~m}$ spatial resolution. We adjusted display histograms to the same brightness and contrast as the Ikonos images. We geographically registered the aerial photographs to the Ikonos images using 5937 control points and formed mosaics that matched the extent and $1 \mathrm{~m}$ spatial resolution of each Ikonos image.

Using ENVI 4.6.1 GIS software, we viewed all images at the same brightness on a MacBook Pro color liquid crystal display with dimensions $33 \mathrm{~cm}$ by $20.7 \mathrm{~cm}$ ( 1440 pixels by 900 pixels) and 32 bit color depth. Using the Ikonos image centers as base points, we divided each research area into $1 \mathrm{~km}^{2}$ cells and delimited a 1 ha square sample area at the center of each cell. The Njóobéen Mbataar area had 200 sample areas, the Fété Olé area had 182 sample areas (because of incomplete aerial photo coverage on the east edge), and the Wolum area had 198 sample areas (because of incomplete aerial photo coverage in the southwest corner and because one sample fell inside a village). Each area also had four field quadrats. To confirm the independence of the samples, we calculated global Moran's I (Anselin, 1995), an index of spatial autocorrelation, on tree density for each research area and year.

To calibrate aerial photo and Ikonos image data to the field measurements of trees, we established the image properties of field trees of $h \geq 3 \mathrm{~m}$. For each aerial photo mosaic and Ikonos image, we determined thresholds of minimum and mean tree center darkness, crown area, and contrast between the crown and the surrounding area of trees of $h \geq 3 \mathrm{~m}$ in the 12 field quadrats and, to generate an adequate sample size for the Wolum area, six adjacent 1-ha sample areas in the Wolum 2002 Ikonos scene.

To complete the calibration of aerial photo and Ikonos image data to the field measurements of trees, we compared the number of trees appearing in Ikonos images viewed at 1:7500 scale to the trees of $h \geq 3 \mathrm{~m}$ measured in the 12 field quadrats. Previous validation of tree counts derived from 1989 aerial photos against field inventories showed no statistical difference between dots visible at $1: 7500$ scale and trees of $h \geq 3 \mathrm{~m}$ measured in the field (Gonzalez, 2001).

At 1:7500 scale, we viewed each sample area and quadrat in each aerial photo mosaic and Ikonos image. Using the aerial photo and Ikonos thresholds (Table A2) to determine objects to include as trees, we counted trees of $h \geq 3 \mathrm{~m}$ and created GIS point files of their locations. To reduce viewing errors, we repeated the tree counts three times for each research area and year.

We calculated 2002 tree densities by dividing raw tree counts from Ikonos by the fraction of field trees visible in Ikonos images (Table A3). To calculate tree mortality, we tracked individual trees through all time periods. To calculate significance of net differences in tree density, we used heteroscedastic $t$-tests on paired data.

\subsection{Tree species richness}

From January 2000 to May 2002, we visited the 14 research villages. Each village identified male and female elders $\sim 60$ years old whom we interviewed as a group. We proceeded through a list of 161 Sahel, Sudan, and Guinea tree and shrub species present in the Sahel (Table A1), identified by local name, and asked them to identify species as present or absent in the village lands in 1960, a year memorable as the year of independence of each country from France, and in 2000. We used botanical characteristics to verify the identity of species. We also asked them to identify any tree or shrub species that we had not already listed. Before and after speaking with the villagers, we independently surveyed village lands to validate their information on species distributions in 2000.

We calculated species richness (number of species) and tree species composition (fraction of all species that were characteristic of each ecological zone). To normalize results among village lands of a range of surface areas, we calculated 1960-2000 changes as a fraction of 1960 values. To calculate significance of differences, we used heteroscedastic $t$-tests on paired data.

\subsection{Attribution of causes of change}

To attribute causes of changes in tree density and tree species richness, we conducted four canonical correlations analyses (CCA; Hotelling, 1936), including one for each research area and one for the group of research village areas. We used CCA to examine the relative influence of four fundamental factors-temperature, precipitation, soil, and population-on tree density and tree species richness. Previous research has applied CCA to the attribution of causes of changes in Sahel tree density and species composition (Gonzalez, 2001) and to other direct comparisons of factors influencing the distribution of tree species (e.g. Carleton, 1984; Pélissier et al., 2002). To assess the robustness of CCA results and further examine relationships between dependent and independent variables, we also calculated bivariate correlations for each pair of variables and the significance of the correlations.

For Njóobéen Mbataar, we conducted CCA on nine variables: tree density in 1954, 1989, and 2002, tree density change as a fraction of original tree density for the periods 1954-1989, 1989-2002, and 1954-2002 (dependent variables); 1950-2000 mean temperature and precipitation (Hijmans et al., 2005), population density in 2008 (Dobson et al., 2000) (independent variables). Only one soil type occurs in the Njóobéen Mbataar area (FAO et al., 2009), reflecting low variation in the area's soil characteristics, so soil was not included in the Njóobéen Mbataar CCA. For Fété Olé and Wolum, we conducted CCA on seven variables: tree density in 1954 and 2002, tree density change from 1954 to 2002 as a fraction of 1954 tree density (dependent variables); 1950-2000 mean temperature and precipitation (Hijmans et al., 2005), topsoil (0-30 cm depth) organic carbon fraction (FAO et al., 2009), population density in 2008 (Dobson et al., 2000) (independent variables). We projected all data from the geographic reference system at a spatial resolution of $30 \mathrm{~s}$ to the equal-area Universal Transverse Mercator (UTM) projection at a spatial resolution of $1 \mathrm{~km}$.

For the set of Sahel village areas, we conducted CCA on seven variables: tree species richness in 1960 and 2000, change in tree species richness as a fraction of 1960 richness (dependent variables); 1950-2000 mean temperature and precipitation (Hijmans et al., 2005), topsoil (0-30 cm depth) organic carbon fraction (FAO et al., 2009), population density in 2008 (Dobson et al., 2000) (independent variables). We used the UTM data at $1 \mathrm{~km}$ spatial resolution. To estimate parameter values for each terroir villageois (each set of village lands), we calculated average values for the $4 \mathrm{~km}^{2}$ (four pixels) around each village, the approximate extent estimated by village residents and an area consistent with previous analyses (Gonzalez, 2001).

To examine if tree density and species richness change were attributable to climate change, we determined if each research area and research village was located in an area of 20th century climate 
change. This contributed to a method of joint attribution previously used to connect historical ecological changes to anthropogenic climate change (Rosenzweig et al., 2008). We used the University of East Anglia Climate Research Unit TS 2.1 data set of 1901-2002 climate (Mitchell and Jones, 2005), from which the Intergovernmental Panel on Climate Change has detected significant changes in temperature and precipitation (Trenberth et al., 2007) and attributed the detected changes to anthropogenic climate forcing (Hegerl et al., 2007). We projected the data from the geographic reference system at a spatial resolution of $0.5^{\circ}$ to Lambert Azimuthal EqualArea projection at a spatial resolution of $50 \mathrm{~km}$ and derived climate trends by linear least squares regression of observed mean annual temperature and annual precipitation versus time (Gonzalez et al., 2010).

\subsection{Limitations of the methods}

Aerial photos and Ikonos satellite images differed in quality. Ikonos images showed finer detail, demonstrated by smaller thresholds for detecting trees (Table A2). This difference would tend to cause undercounting of trees in the aerial photos, implying that tree density decreased even more than estimated. Calibration of Ikonos data to field observations showed that tree counts derived from Ikonos underestimated field densities (Table A3). Consequently, we calculated 2002 tree densities by dividing raw tree counts by the fraction visible in each area, further narrowing the difference between tree densities derived from aerial photos and Ikonos images. We validated our tree counts at Fété Olé against field inventories of the same area by Poupon (1980).

For the species surveys, recollections of the presence or absence of species served as a proxy for non-existent data on historical distributions. Although recollections are inexact, we systematically recorded just one piece of binary information (presence $=1$, absence $=0$ ) for each species for each year and used a past year marked by a memorable event. We verified the accuracy of villagers' responses on current species through our own field observations. Previous validation of local knowledge of tree species gave an error rate of $1 \%$ of data points (Gonzalez, 2001), equivalent to approximately one species for each of the 14 Sahel village areas.

For the attribution of causes, we recognize that our choice of four independent variables is a simplification. We sought to account for the myriad environmental and socio-economic variables involved by selecting the fundamental factors most influencing tree cover in the Sahel. Availability of spatial data also constrained our choice of variables. Furthermore, we have sought to account for complex interactions among variables by using CCA, a multivariate statistical method that systematically examines the relationships of every pair of variables and calculates the influence of each independent variable on the observed variability of all the dependent variables. Although CCA provides a comprehensive comparison of the relationships of sets of dependent and independent variables, canonical loadings prove correlation not causation.

Although data on mean climate are available at $1 \mathrm{~km}$ spatial resolution (Hijmans et al., 2005), data on climate trends are only available at $50 \mathrm{~km}$ spatial resolution (Mitchell and Jones, 2005; Gonzalez et al., 2010). Although data on population density are available (Dobson et al., 2000), consistent data on population trends are not available. In addition, the LandScan population density data (Dobson et al., 2000) were only available for 2008 because the developers do not distribute data from previous years.

\section{Results}

\subsection{Tree density}

Field counting and measurement of 1503 live trees in the 12 quadrats (Table 1) showed that Fété Olé had the highest tree density while Njóobéen Mbataar had the highest species richness and highest fractions of trees of Sudan and Guinean species. Because we only found four dead trees and because all of them were small $(h<40 \mathrm{~cm})$, we analyzed data from only the live trees. Validation of our tree counts against a field inventory of the 25 ha site at Fété Olé (Poupon, 1980) shows general agreement, with a $29 \%$ decrease in tree density (1972-1976) derived from field data and a 20\% decrease (1954-2002) derived from aerial photos and Ikonos. Spatial autocorrelation was low in all research areas, with the following values of global Moran's I: 0.163, 0.067, 0.016 (Njóobéen Mbataar 1954, 1989, 2002); 0.145, 0.052 (Fété Olé 1954, 2002); 0.065, 0.035 (Wolum 1954, 2002).

We found significant decreases in tree density at Njóobéen Mbataar from 1954 to 1989 and from 1954 to 2002 and at Fété Olé from 1954 to 2002 (Fig. 2). At both Njóobéen Mbataar and Fété Olé, tree density fell one-fifth from 1954 to 2002 and fell in over half the samples (Table A4). At Wolum, tree density fell in one-third of the samples, but net change in average density was not significant. By tracking individual trees (Fig. 3), we found that tree mortality rates ranged from $0.11 \pm 0.01$ decade $^{-1}$ at Wolum to $0.33 \pm 0.04$ decade $^{-1}$ at Njóobéen Mbataar (Table A4). Tree density and tree density change displayed substantial spatial variation across each research area (Figs. A1-A3).

\subsection{Tree species richness}

Field surveys recorded 116 tree and shrub species in the 14 village areas (Table A1), with the following species composition: Sahel species 29\%, Sudan species 39\%, Guinean species $32 \%$. The family Mimosaceae had the highest number of species of each ecological zone, with Capparaceae (Sahel), Caesalpiniaceae (Sudan), and Moraceae (Guinea) representing the second highest number of species of each ecological zone. Tree species richness declined in 12 village areas and remained unchanged in two village areas (Table A5).

We found a significant decrease in tree species richness in the group of village areas from 1960 to 2000 (Fig. 2). Tree species richness of each of the three ecological zones fell significantly, with the rate of decrease in Guinean species double the rate of decrease in Sahel species (Table 2). As a fraction of all tree species, Sahel species increased significantly while Guinean species decreased significantly (Table 2).

Table 1

Tree densities and tree species (mean \pm standard deviation [SD]) by research area, listed from west to east.

\begin{tabular}{|c|c|c|c|c|c|c|c|c|c|c|c|c|}
\hline \multirow[t]{2}{*}{ Research area } & \multirow[t]{2}{*}{ Country } & \multicolumn{4}{|c|}{ Tree density (trees ha ${ }^{-1}$ ) } & \multicolumn{2}{|c|}{$\begin{array}{l}\text { Species richness } \\
\text { (species) }\end{array}$} & \multicolumn{3}{|c|}{ Species composition (fraction of all trees) } & \multirow[t]{2}{*}{$\begin{array}{l}\text { Trees } \\
\text { counted }\end{array}$} & \multirow[t]{2}{*}{$n$} \\
\hline & & $h<40 \mathrm{~cm}$ & $40 \mathrm{~cm} \leq \mathrm{h}<3 \mathrm{~m}$ & $h \geq 3 \mathrm{~m}$ & All trees & Mean & Total & Sahel & Sudan & Guinea & & \\
\hline Njóobéen Mbataar & Senegal & $33 \pm 18$ & $87 \pm 24$ & $9.5 \pm 8.8$ & $130 \pm 33$ & $10 \pm 2$ & 18 & $0.55 \pm 0.20$ & $0.40 \pm 0.18$ & $0.05 \pm 0.02$ & 518 & 4 \\
\hline Fété Olé & Senegal & $12 \pm 7.2$ & $134 \pm 77$ & $21 \pm 11$ & $167 \pm 89$ & $6 \pm 3$ & 13 & $0.99 \pm 0.30$ & $0.01 \pm 0.03$ & 0 & 669 & 4 \\
\hline Wolum & Mauritania & $12 \pm 9.0$ & $67 \pm 69$ & $0.2 \pm 0.5$ & $79 \pm 79$ & $4 \pm 3$ & 9 & $0.83 \pm 0.34$ & $0.17 \pm 0.34$ & 0 & 316 & 4 \\
\hline
\end{tabular}


a Tree species richness Sahel

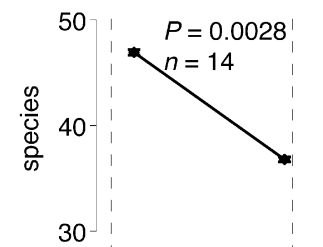

b Tree density Fété Olé
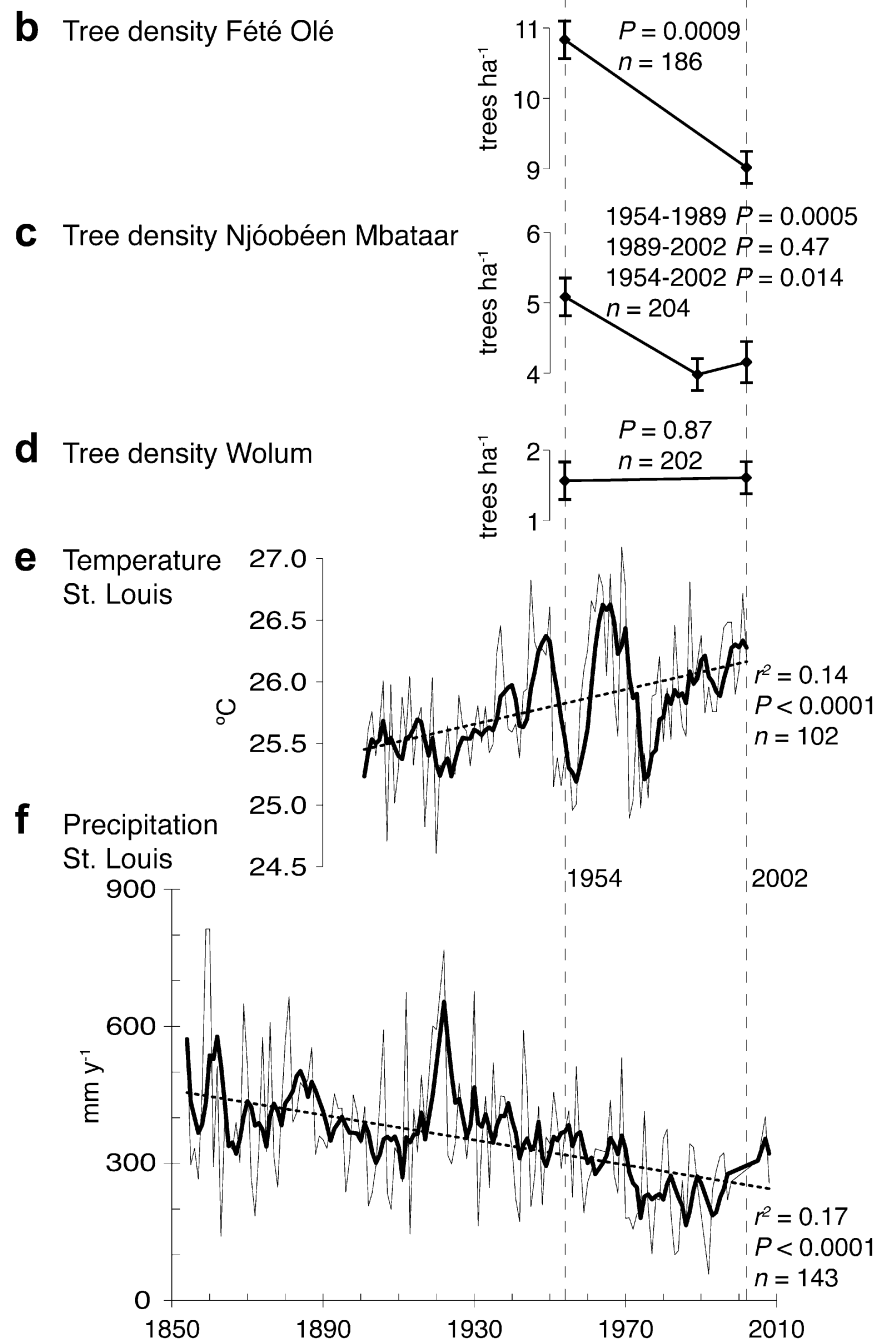

Fig. 2. Changes in tree cover and climate. (a) Decrease in tree species richness of village areas. (b) Decrease in tree density at Fété Olé. (c) Changes in tree density at Njóobéen Mbataar. (d) Changes in tree density at Wolum. (e) Mean temperature (calculated from data from Mitchell and Jones (2005); thin line) from 1901 to 2002 at St. Louis, Senegal $\left(16.1^{\circ} \mathrm{N}, 16.5^{\circ} \mathrm{W}\right.$; location shown in Fig. 1a), running five-year mean (thick line), and significant trend (dotted line) from least squares linear regression. (f) Annual precipitation (thin line; calculated from data from Aubréville (1938) and from National Oceanic and Atmospheric Administration, Global Historical Climatology Network, http://www.ncdc.noaa.gov/oa/climate/ghcn-monthly/index.php) from 1854 to 2008 at St. Louis, Senegal, running five-year mean (thick line), and significant trend (dotted line) from least squares linear regression.

\subsection{Attribution of causes of change}

Temperature had the highest rotated loading for canonical function (CF) 1 for all four CCAs and precipitation had the second highest rotated loading for CF 1 for three CCAs (Table A6). All corresponding loadings were significant $(P<0.0001)$. For $C F 2$, topsoil organic carbon had the highest rotated loading for Wolum and the Sahel villages, population had the highest rotated loading for Njóobéen Mbataar, and precipitation had the highest rotated loading for Fété Olé (Table A6).
In bivariate correlation tests, tree density change (1954-2002) at Njóobéen Mbataar showed significant correlation with temperature $\left(r^{2}=0.21, P=0.003, n=200\right)$ and precipitation $\left(r^{2}=-0.21\right.$, $P=0.002, n=200)$. Species richness change $(1960-2000)$ in the Sahel villages showed significant correlation with temperature $\left(r^{2}=0.67, P=0.009, n=14\right)$. Tree density and tree species richness changes did not show significant bivariate correlations with topsoil organic carbon or population density.

According to government censuses, population grew in the administrative regions of all three research areas: Njóobéen Mbataar, 0.02 year $^{-1}$ (Région de Louga, 1976-2002, http://www.ansd. sn); Fété Olé, 0.01 year $^{-1}$ (Région de St. Louis, 1976-2002, http:// www.ansd.sn); Wolum, 0.03 year $^{-1}$ (Moughataa de M'Bagne, 1977-2000, http://www.ons.mr). Population growth was highest in Wolum, the only area where tree density did not significantly change.

The detected changes in tree density and species richness occurred in areas of climate change (Table 3, Fig. 4). At all three research areas, temperature increased and rainfall decreased significantly in the 20th century. The meteorological station at St. Louis, Senegal, 30-300 km west of the research areas (location shown in Fig. 1a), has recorded the longest rainfall data series in Africa and documented the rainfall decline, showing a significant linear trend of $-1.4 \mathrm{~mm}_{\text {year }^{-2}}$ from 1854 to 2008 (Fig. 2). Temperature in the St. Louis region showed a significant linear trend of $0.7{ }^{\circ} \mathrm{C}$ century $^{-1}$ from 1901 to 2002 (Fig. 2). Twentieth century temperature increased in 13 village areas, with significant increases in 10 village areas (Table 3, Fig. 4). Rainfall decreased in 12 village areas, with significant decreases in three village areas. Whereas temperature increased and precipitation decreased for most of the areas, covariance of temperature change with precipitation change was low across the Sahel (covariance $=-0.02$ for the land area of Fig. 4).

In summary, during the 20th century, average tree species richness decreased significantly in the research village areas (Fig. 2a), tree density decreased significantly in two research areas (Fig. 2b and c), but remained stable in the most arid area (Fig. 2d), temperature increased significantly (Fig. 2e), and precipitation decreased significantly (Fig. 2f).

\section{Discussion}

\subsection{Significant declines in tree density and species richness}

The significant changes in tree density at Njóobéen Mbataar and Fété Olé provide evidence of tree density declines in the western Sahel. The decreases in tree density occurred at rates close to the rates previously found in parts of the two areas (Gonzalez, 2001; Vincke et al., 2010). Our sampling was more intensive in the Njóobéen Mbataar area and more extensive in the Fété Olé area than previous research (Poupon, 1980; Gonzalez, 2001; Vincke et al., 2010). Although the change at Wolum was not significant, tree density at Wolum was one-fifth and one-tenth the densities at Njóobéen Mbataar and Fété Olé, respectively, and 1950-2000 mean temperature was $2{ }^{\circ} \mathrm{C}$ and $4{ }^{\circ} \mathrm{C}$ warmer, respectively. It is possible that arid conditions had already thinned trees to low densities before 1954 .

A significant decline in tree density at Njóobéen Mbataar from 1954 to 1989 , followed by no significant change from 1989 to 2002 (Fig. 2c), is consistent with observations by local residents and data from Fété Olé (Poupon, 1980) of substantial tree mortality in the 1970s and 1980s. The 154-year record of precipitation at St. Louis, Senegal (Fig. 2f) shows a significant rainfall decline that hit its nadir in the period 1968-1973, when rainfall fell to approximately one standard deviation below the long-term average five out of six 

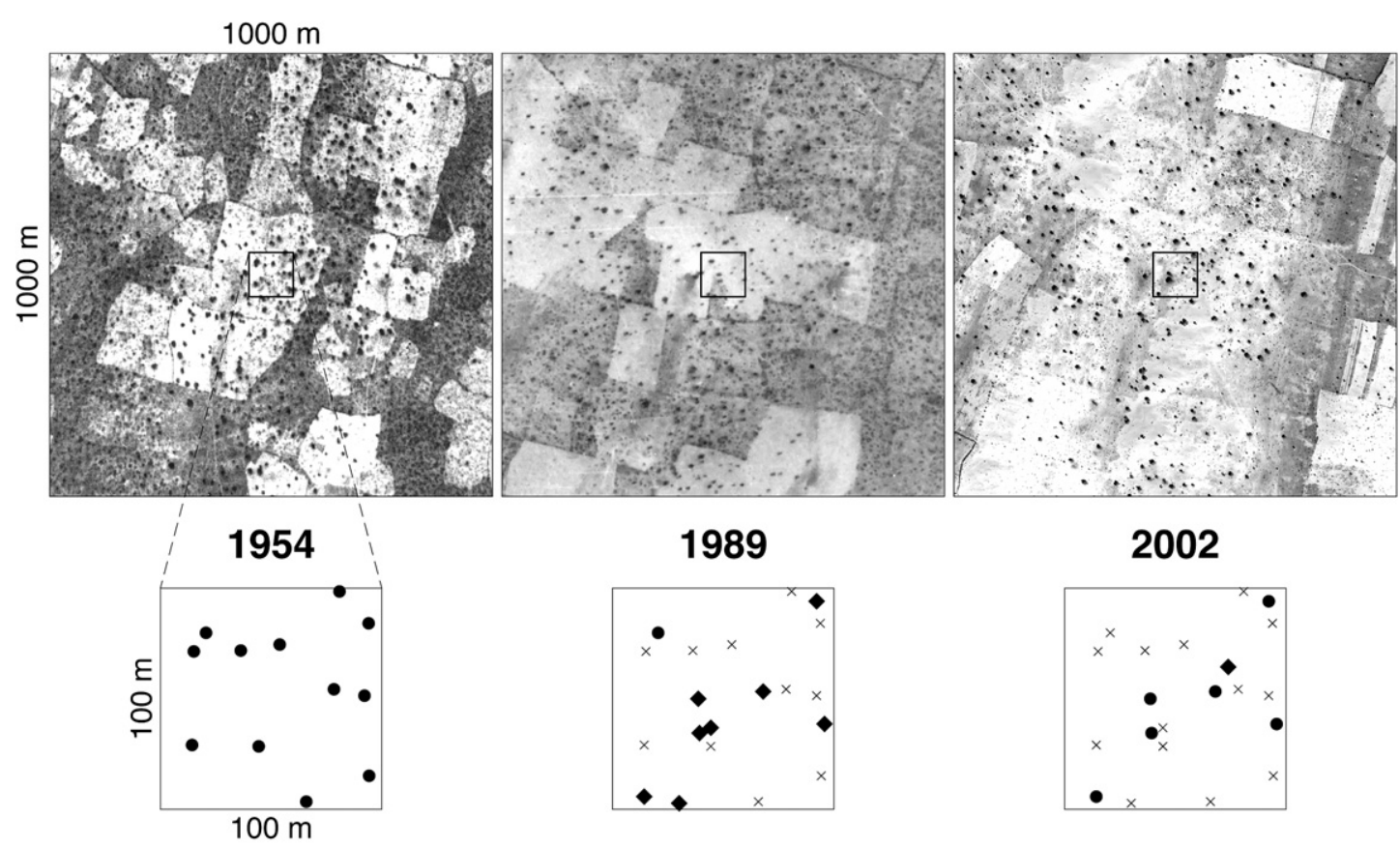

$\bullet$ live tree $\bullet$ new tree $\times$ tree died

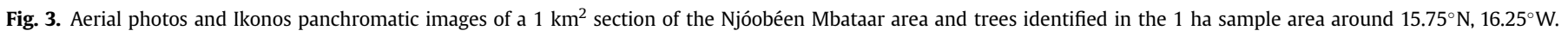

years. This is a possible threshold of resilience to drought stress for Sudan and Guinean tree species.

The significant declines in tree density in Senegal (Poupon, 1980; Gonzalez, 2001; Vincke et al., 2010; this research) contrast with cases of no significant change or increases in tree or shrub density at sites in Burkina Faso, Mali, and the Republic of the Sudan (Schlesinger and Gramenopoulos, 1996; Rasmussen et al., 2001; Hiernaux et al., 2009). This suggests that the heterogeneity of environmental conditions in the Sahel has led to uneven changes in tree cover. In addition, the significant decline of tree density at Njóobéen Mbataar and Fété Olé from 1954 to 2002 contrasts with the lack of significant change in NDVI in the two areas from 1982 to 1999 (Seaquist et al., 2006). This demonstrates that tree density can reveal long-term trends undetectable by NDVI because of the starting year of the NDVI time series and its closer relationship, in the Sahel, to herbaceous cover rather than tree cover.

The significant decrease in tree species richness in the group of 14 village areas and the replacement of mesic species by xeric species is consistent with changes in tree species at numerous sites in Burkina Faso, Niger, and Senegal (Gonzalez, 2001; Rasmussen et al., 2001; Wezel and Lykke, 2006; Maranz, 2009). The two village areas where we found no change in tree species richness, Fabugu and Kaylaroom, are located in the floodplain of the Niger River and the basin of Lake Chad, respectively, suggesting that a high water table maintained favorable soil moisture, conserving mesic species.

In the remaining research villages, the decrease in Guinean species as a fraction of all species and the increase in Sahel species as a fraction of all species indicate a shift of the Sahel zone southward into areas of increased aridity and a concomitant shift of the Guinean zone southward toward more humid areas, a vegetation shift previously documented in Senegal (Gonzalez, 2001). The results indicate a retraction of Guinean species and southward shift of the Sahel-Sudan and Sudan-Guinea ecotones.

In summary, the decreases in tree density in the western Sahel and tree species richness across the Sahel together provide evidence of a decline of tree cover in the Sahel in the last half of the 20th century. Two different types of tree data-density and species richness-drawn from different samples both showed significant declines. Tree density at Njóobéen Mbataar and Fété Olé and tree species richness in the research villages declined at similar rates.

\subsection{Attribution to climate variability and joint attribution to climate change}

Canonical correlations analyses indicate that temperature variability dominated all factors in explaining observed patterns of tree density and species richness. Precipitation variability was almost as

Table 2

Tree species richness, tree species composition, and changes (mean \pm SD).

\begin{tabular}{|c|c|c|c|c|c|c|c|c|c|c|c|}
\hline \multirow{3}{*}{$\begin{array}{l}\text { Ecological } \\
\text { zone }\end{array}$} & \multirow{2}{*}{\multicolumn{2}{|c|}{$\begin{array}{l}\text { Species richness } \\
\text { (species) }\end{array}$}} & \multicolumn{4}{|c|}{ Species richness change } & \multirow{2}{*}{\multicolumn{2}{|c|}{$\begin{array}{l}\text { Species composition } \\
\text { (fraction of all species) }\end{array}$}} & \multicolumn{2}{|c|}{ Species composition change } & \multirow[t]{3}{*}{$n$} \\
\hline & & & \multirow[t]{2}{*}{ (species) } & \multirow[t]{2}{*}{ (fraction) } & \multirow{2}{*}{$\left(\right.$ decade $\left.^{-1}\right)$} & \multirow[t]{2}{*}{$P$} & & & \multirow{2}{*}{$\begin{array}{l}\text { (fraction of } \\
\text { all species) }\end{array}$} & \multirow[t]{2}{*}{$P$} & \\
\hline & 1960 & 2000 & & & & & 1960 & 2000 & & & \\
\hline Sahel & $17 \pm 2$ & $15 \pm 2$ & $-2 \pm 2$ & $-0.13 \pm 0.10$ & $-0.03 \pm 0.02$ & 0.0140 & $0.38 \pm 0.07$ & $0.43 \pm 0.07$ & $0.04 \pm 0.03$ & 0.0047 & 14 \\
\hline Sudan & $18 \pm 3$ & $15 \pm 3$ & $-3 \pm 3$ & $-0.18 \pm 0.12$ & $-0.04 \pm 0.03$ & 0.0188 & $0.39 \pm 0.03$ & $0.40 \pm 0.03$ & $0.01 \pm 0.03$ & 0.3243 & 14 \\
\hline Guinea & $12 \pm 4$ & $7 \pm 3$ & $-4 \pm 2$ & $-0.35 \pm 0.17$ & $-0.09 \pm 0.04$ & 0.0010 & $0.23 \pm 0.06$ & $0.17 \pm 0.06$ & $-0.06 \pm 0.03$ & 0.0011 & 14 \\
\hline All & $47 \pm 7$ & $37 \pm 7$ & $-10 \pm 6$ & $-0.21 \pm 0.11$ & $-0.05 \pm 0.03$ & 0.0028 & 1.00 & 1.00 & - & - & 14 \\
\hline
\end{tabular}


Table 3

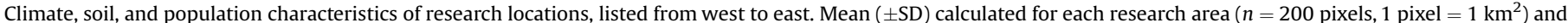

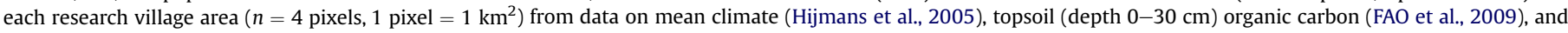

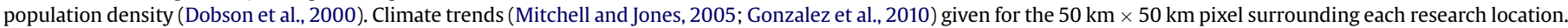
Significance of climate trends from linear regression: ${ }^{*} P \leq 0.05,{ }^{* *} P \leq 0.01,{ }^{* * *} P \leq 0.001$.

\begin{tabular}{|c|c|c|c|c|c|c|c|}
\hline & \multirow[t]{2}{*}{ Country } & \multirow{2}{*}{$\begin{array}{l}\text { Mean temperature } \\
\left({ }^{\circ} \mathrm{C}\right) \\
1950-2000\end{array}$} & \multirow{2}{*}{$\begin{array}{l}\text { Temperature trend } \\
\left({ }^{\circ} \mathrm{C}_{\text {century }}{ }^{-1}\right)\end{array}$} & \multirow{2}{*}{$\frac{\begin{array}{l}\text { Mean precipitation } \\
\left(\mathrm{mm}_{\mathrm{year}}{ }^{-1}\right)\end{array}}{1950-2000}$} & \multirow{2}{*}{$\begin{array}{l}\begin{array}{l}\text { Precipitation } \\
\text { trend }\left(\text { century }^{-1}\right)\end{array} \\
1901-2002\end{array}$} & \multirow[t]{2}{*}{$\begin{array}{l}\text { Soil organic } \\
\text { carbon (\%) }\end{array}$} & \multirow{2}{*}{$\begin{array}{l}\text { Population density } \\
\text { (people } \mathrm{km}^{2} \text { ) } \\
2008\end{array}$} \\
\hline & & & & & & & \\
\hline \multicolumn{8}{|l|}{ Research areas } \\
\hline Njóobéen Mbataar & Senegal & $25.3 \pm 0.08$ & $0.7^{* * *}$ & $330 \pm 9$ & $-0.48^{* * *}$ & 0.3 & $79 \pm 170$ \\
\hline Fété Olé & Senegal & $27.6 \pm 0.03$ & $0.8^{* * *}$ & $290 \pm 9$ & $-0.42^{* * *}$ & $0.2 \pm 0.05$ & $13 \pm 4$ \\
\hline Wolum & Mauritania & $29.5 \pm 0.07$ & $0.7^{* * *}$ & $260 \pm 7$ & $-0.31^{*}$ & $0.9 \pm 0.3$ & $39 \pm 110$ \\
\hline \multicolumn{8}{|l|}{ Research village areas } \\
\hline Juude Waalo & Mauritania & $29.3 \pm 0.02$ & $0.7^{* * *}$ & $240 \pm 1$ & $-0.31^{*}$ & $0.6 \pm 0.7$ & $480 \pm 940$ \\
\hline Aten & Mauritania & $29.5 \pm 0.04$ & $0.7^{* * *}$ & $240 \pm 1$ & $-0.31^{*}$ & 1.2 & $270 \pm 460$ \\
\hline Fabugu & Mali & $27.2 \pm 0.03$ & $0.8^{* * *}$ & $590 \pm 2$ & $-0.24^{* *}$ & 0.7 & $57 \pm 30$ \\
\hline Nampabuum & Burkina Faso & $28.3 \pm 0.01$ & $0.6^{* * *}$ & $600 \pm 1$ & -0.12 & 0.8 & $410 \pm 630$ \\
\hline Banizumbi & Niger & $29.2 \pm 0.01$ & $0.4^{*}$ & $380 \pm 1$ & -0.02 & 0.5 & $56 \pm 91$ \\
\hline Tamaka & Niger & $28.7 \pm 0.02$ & 0.3 & $440 \pm 3$ & 0.02 & 0.4 & $86 \pm 53$ \\
\hline Dan Tsuntsu & Niger & $27.4 \pm 0.01$ & $<0.1$ & $360 \pm 1$ & -0.07 & 0.4 & $210 \pm 330$ \\
\hline Guidimouni & Niger & $27.6 \pm 0.25$ & $-0.01^{*}$ & $320 \pm 2$ & -0.02 & 0.5 & $54 \pm 44$ \\
\hline Kaylaroom & Chad & $27.8 \pm 0.02$ & 0.1 & $290 \pm 1$ & 0.09 & 0.4 & $1 \pm 1$ \\
\hline Buurtey Ganuun & Chad & $29.3 \pm 0.04$ & $0.4^{*}$ & $350 \pm 1$ & -0.10 & 1.4 & 4 \\
\hline Marchuut & Chad & $28.8 \pm 0.02$ & $0.4^{*}$ & $440 \pm 2$ & -0.10 & 1.4 & $11 \pm 9$ \\
\hline Akar & Chad & $28.8 \pm 0.05$ & $0.4^{*}$ & $380 \pm 2$ & -0.10 & 1.4 & $39 \pm 65$ \\
\hline Kardofal & Chad & $27.9 \pm 0.03$ & $0.5^{*}$ & $480 \pm 2$ & -0.15 & 0.4 & $4 \pm 2$ \\
\hline Ningelin & Chad & $28.1 \pm 0.03$ & $0.5^{*}$ & $450 \pm 2$ & -0.15 & 1.1 & $3 \pm 2$ \\
\hline
\end{tabular}

important as temperature variability, based on the loadings for CF 1 . Whereas tree density change showed significant correlation with temperature and precipitation at Njóobéen Mbataar and tree species richness change showed significant correlation with temperature in the research villages, tree density change and tree species richness change showed no correlation with topsoil organic carbon or population.

Field observations and interpretation of aerial photos and Ikonos images confirm that tree density is not consistently higher or lower close to population centers (villages or large towns). Local people generally do not fell live mature trees for firewood, but periodically coppice (cut near the root crown) young shrubs, which resprout for future firewood harvesting. Tree density and tree species richness have declined in uninhabited areas to the west of Njóobéen Mbataar (Gonzalez, 2001), further suggesting a dominant cause other than local human population. In addition, even though the region around Wolum experienced the highest population growth rate of the three research areas, Wolum was the only research area where tree density did not significantly change.

Precipitation dominated population in explaining tree cover change even though the rate of population growth of the three research areas exceeded the rate of precipitation decline by factors
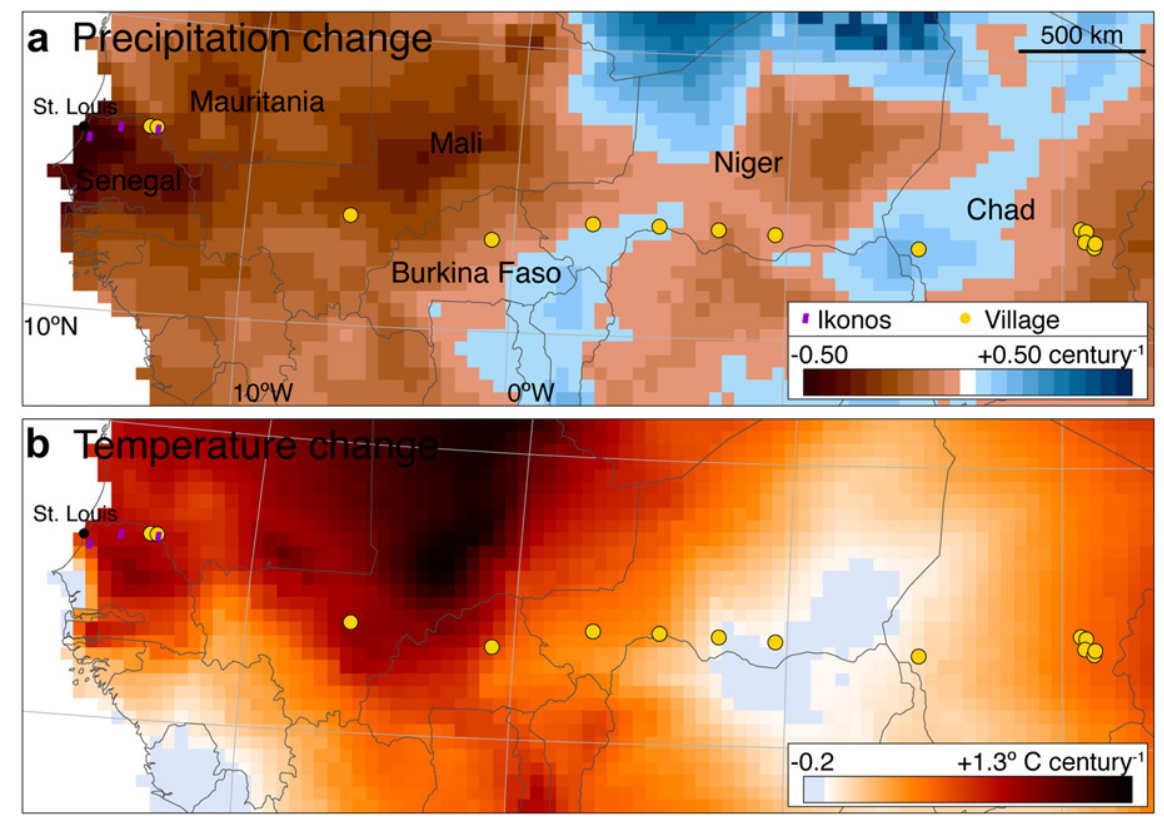

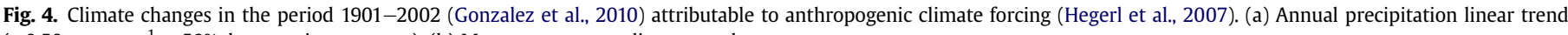
$\left(-0.50\right.$ century $^{-1}=50 \%$ decrease in a century). (b) Mean temperature linear trend. 
of five and three at Njóobéen Mbataar and Fété Olé, respectively. In contrast, tree density (Table A4) and rainfall (Table 3) declined at similar rates at Njóobéen Mbataar and Fété Olé.

Because the CCA results, bivariate correlations, and field observations consistently indicate the dominant influence of temperature and precipitation variability, we attribute the detected changes in tree density and tree species richness to climate variability. A convergence of 20th century trends of increasing temperature and decreasing precipitation, tree density, and species richness (Fig. 2) illustrates the effect of climate. While our analyses indicate that climate factors predominate over population in explaining overall patterns of tree cover change across the region, we recognize that people can still affect tree density and tree species richness at specific locations. Still, the predominance that we find of climate over population and soil in explaining overall patterns of tree cover in the Sahel is consistent with continental-scale analyses of the factors governing tree cover in Africa (Sankaran et al., 2005).

We connect Sahel tree cover changes to global climate change in a two-step method known as joint attribution (Rosenzweig et al., 2008): (1) attribution of tree cover changes to Sahel climate variability (20th century temperature and precipitation change) and (2) attribution of Sahel climate variability to global climate change. Our CCA results, bivariate correlations, and field observations provide evidence for step 1 . Our detection of changes in tree density and species richness in areas of 20th century climate change (Table 3 , Fig. 4) and previous research that attributes the two principal forms of 20th century Sahel climate variability to global climate change (Wang and Eltahir, 2002; Held et al., 2005; Biasutti and Giannini, 2006; Hegerl et al., 2007; Zhang et al., 2007) provide evidence for step 2.

The combination of warmer temperatures and significant decreases in precipitation in the three research areas and three village areas increased aridity and water stress on trees. The detected changes in tree cover were outside the range of spatial variation in each area and consistent with process-level understanding of the vulnerability of mesic tree species to aridity. Drought can kill trees through cavitation of water columns within the xylem and through carbohydrate deficits that reduce resistance to pests (Allen et al., 2010).

The joint attribution of Sahel tree cover change to global climate change is consistent with cases of drought-induced tree dieback around the world associated with climate change (Allen et al., 2010). Furthermore, the detected southward shift of the Sahel, Sudan, and Guinean zones is similar to vegetation shifts attributed to climate change at numerous sites around the world (Gonzalez et al., 2010). These results are consistent with the joint attribution of $>90 \%$ of detected ecological changes in 29,000 data series around the world to anthropogenic climate change (Rosenzweig et al., 2008).

\section{Conclusions}

Using field measurements of trees, field surveys of tree species, aerial photos, Ikonos satellite images, multivariate analyses of temperature, precipitation, soil, and population, and spatial analyses of climate change data, we have shown that:

1. Tree density declined significantly from 1954 to 2002 in the western Sahel at Njóobéen Mbataar and Fété Olé, Senegal.

2. Tree species richness declined significantly from 1960 to 2000 across the Sahel in a sample of 14 village areas in Mauritania, Mali, Burkina Faso, Niger, and Chad.

3. The detected tree cover changes are attributable to two forms of climate variability-increasing temperature and decreasing precipitation-and jointly attributable to global climate change.
This detection and attribution of tree cover changes can help guide future adaptation measures for natural resource management in the Sahel. One adaptation measure to maintain and augment tree cover is natural regeneration, a traditional practice in which farmers and herders select small field trees, protect them, prune them, and raise them to maturity. In parts of the Sahel, natural regeneration has doubled the density of mature trees (Lericollais, 1989).

Our results suggest that natural regeneration should concentrate on a mix of tree species that are more drought-tolerant than those that might currently occupy a field. Drought-tolerant trees include Sahel species like Acacia raddiana and Balanites aegyptiaca, which, although not as highly desired by local people for fruit or wood as Sudan species like Mangifera indica or Guinean species like Bombax costatum, are more likely to survive arid conditions. In addition to natural regeneration, field water harvesting and other practices tested across the Sahel (Larwanou and Saadou, 2011) offer alternatives for future adaptation.

Because the reduction in tree cover in the Sahel may contribute to wind erosion, reduced soil organic matter, and other forms of land degradation, it shows how climate change may exacerbate desertification. Consequently, adaptation measures to increase tree cover could help to reduce the vulnerability of local people to both climate change and desertification.

Finally, the connection of Sahel vegetation change to global climate change suggests that global greenhouse gas emissions reductions should accompany any local adaptation measures in the Sahel.

\section{Acknowledgments}

We gratefully acknowledge field work assistance by Alkhalil Adoum, Elaine Carlson, Issa Khalil, Joseph Sedgo, and Salif Sow, comments from Paul R. Ehrlich, support from Christine A. Rose, allocation of Ikonos images from the NASA Scientific Data Purchase, research funding from NASA and the U.S. Geological Survey, and assistance from the residents of Akar, Aten, Banizumbi, Buurtey Ganuun, Dan Tsuntsu, Fabugu, Fété Olé, Guidimouni, Juude Waalo, Kardofal, Kaylaroom, Marchuut, Nampabuum, Ningelin, Njóobéen Mbataar, Tamaka, and Wolum.

\section{Appendix. Supplementary data}

Supplementary data associated with this article can be found, in the online version, at doi:10.1016/j.jaridenv.2011.11.001.

\section{References}

Allen, C.D., Macalady, A.K., Chenchouni, H., Bachelet, D., McDowell, N., Vennetier, M., Kitzberger, T., Rigling, A., Breshears, D.D., Hogg, E.H., Gonzalez, P., Fensham, R., Zhang, Z., Castro, J., Demidova, N., Lim, J.H., Allard, G., Running, S.W., Semerci, A., Cobb, N., 2010. A global overview of drought and heat-induced tree mortality reveals emerging climate change risks for forests. Forest Ecology and Management 259, 660-684.

Anselin, L., 1995. Local indicators of spatial association-LISA. Geographical Analysis 27, 93-115.

Anyamba, A., Tucker, C.J., 2005. Analysis of Sahelian vegetation dynamics using NOAA-AVHRR NDVI data from 1981-2003. Journal of Arid Environments 63, 596-614.

Aubréville, A., 1938. La Forêt Coloniale-Les Forêts de l'Afrique Occidentale Française. Société d'Éditions Géographiques, Maritimes, et Coloniales, Paris.

Aubréville, A., 1950. Flore Forestière Sudano-Guinéenne. Société d'Éditions Géographiques, Maritimes, et Coloniales, Paris.

Biasutti, M., Giannini, A., 2006. Robust Sahel drying in response to late 20th century forcings. Geophysical Research Letters 33, L11706. doi:10.1029/2006GL026067.

Carleton, T.J., 1984. Residual ordination analysis-a method for exploring vegetation-environment relationships. Ecology 65, 469-477.

Charney, J.G., 1975. Dynamics of deserts and drought in the Sahel. Quarterly Journal of the Royal Meteorological Society 101, 193-202. 
Dai, A., Lamb, P.J., Trenberth, K.E., Hulme, M., Jones, P.D., Xie, P., 2004. The recent Sahel drought is real. International Journal of Climatology 24, 1323-1331.

Dobson, J.E., Bright, E.A., Coleman, P.R., Durfee, R.C., Worley, B.A., 2000. LandScan: a global population database for estimating populations at risk. Photogrammetric Engineering and Remote Sensing 66, 849-857.

Food and Agriculture Organization (FAO), 2001. Global Forest Resources Assessment 2000. FAO, Rome.

Food and Agriculture Organization (FAO), International Institute for Applied Systems Analysis (IIASA), International Soil Reference and Information Centre, Chinese Academy of Sciences Institute of Soil Science, European Commission Joint Research Centre, 2009. Harmonized World Soil Database (Version 1.1). FAO/IIASA, Rome/Laxenburg, Austria.

Giannini, A., Saravanan, R., Chang, P., 2003. Oceanic forcing of Sahel rainfall on interannual to interdecadal time scales. Science 302, 1027-1030.

Gonzalez, P., 2001. Desertification and a shift of forest species in the West African Sahel. Climate Research 17, 217-228.

Gonzalez, P., Neilson, R.P., Lenihan, J.M., Drapek, R.J., 2010. Global patterns in the vulnerability of ecosystems to vegetation shifts due to climate change. Global Ecology and Biogeography 19, 755-768.

Hegerl, G.C., Zwiers, F.W., Braconnot, P., Gillett, N.P., Luo, Y., Marengo Orsini, J.A., Nicholls, N., Penner, J.E., Stott, P.A., 2007. Understanding and attributing climate change. In: Solomon, S., Qin, D., Manning, M., Chen, Z., Marquis, M., Averyt, K.B., Tignor, M., Miller, H.L. (Eds.), Climate Change 2007: The Physical Science Basis. Contribution of Working Group I to the Fourth Assessment Report of the Intergovernmental Panel on Climate Change. Cambridge University Press, Cambridge, pp. 663-745.

Hein, L., de Ridder, N., Hiernaux, P., Leemans, R., de Wit, A., Schaepman, M., 2011. Desertification in the Sahel: towards better accounting for ecosystem dynamics in the interpretation of remote sensing images. Journal of Arid Environments $75,1164-1172$.

Held, I.M., Delworth, T.L., Lu, J., Findell, K.L., Knutson, T.R., 2005. Simulation of Sahel drought in the 20th and 21st centuries. Proceedings of the National Academy of Sciences of the United States of America 102, 17891-17896.

Hiernaux, P., Diarra, L., Trichon, V., Mougin, E., Soumaguel, N., Baup, F., 2009. Woody plant population dynamics in response to climate changes from 1984 to 2006 in Sahel (Gourma, Mali). Journal of Hydrology 375, 103-113.

Hijmans, R.J., Cameron, S.E., Parra, J.L., Jones, P.G., Jarvis, A., 2005. Very high resolution interpolated climate surfaces for global land areas. International Journal of Climatology 25, 1965-1978.

Hotelling, H., 1936. Relations between two sets of variates. Biometrika 28, 321-377.

Hulme, M., Doherty, R., Ngara, T., New, M., Lister, D., 2001. African climate change: 1900-2100. Climate Research 17, 145-168.

Larwanou, M., Saadou, M., 2011. The role of human interventions in tree dynamics and environmental rehabilitation in the Sahel zone of Niger. Journal of Arid Environments 75, 194-200.

Le Houérou, H.N., 1984. Rain use efficiency: a unifying concept in arid-land ecology. Journal of Arid Environments 7, 213-247.

Lericollais, A., 1989. La mort des arbres à Sob, en pays Sereer (Sénégal). In: Benoît, A., Blanc-Pamard, C., Chaléard, J.L. (Eds.), Tropiques: Lieux et Liens. ORSTOM, Paris, pp. 187-197.

Maranz, S., 2009. Tree mortality in the African Sahel indicates an anthropogenic ecosystem displaced by climate change. Journal of Biogeography 36, 1181-1193.

Mitchell, T.D., Jones, P.D., 2005. An improved method of constructing a database of monthly climate observations and associated high-resolution grids. International Journal of Climatology 25, 693-712.

Niang, A.J., Ozer, A., Ozer, P., 2008. Fifty years of landscape evolution in Southwestern Mauritania by means of aerial photos. Journal of Arid Environments 72, 97-107.

Nicholson, S.E., Tucker, C.J., Ba, M.B., 1998. Desertification, drought, and surface vegetation: an example from the West African Sahel. Bulletin of the American Meteorological Society 79, 815-829.

Olsson, L., Eklundh, L., Ardö, J., 2005. A recent greening of the Sahel-trends, patterns and potential causes. Journal of Arid Environments 63, 556-566.

Organisation for Economic Co-Operation and Development (OECD), 1998. Preparing for the Future. A Vision of West Africa in the Year 2020. West Africa Long-Term Perspective Study. OECD, Paris.
Pélissier, R., Dray, S., Sabatier, D., 2002. Within-plot relationships between tree species occurrences and hydrological soil constraints: an example in French Guiana investigated through canonical correlation analysis. Plant Ecology 162. 143-156.

Poupon, H., 1980. Structure et Dynamique de la Strate Ligneuse d'une Steppe Sahélienne au Nord du Sénégal. Office de la Recherche Scientifique et Technique Outre-Mer, Paris.

Prince, S.D., Brown De Colstoun, E., Kravitz, L.L., 1998. Evidence from rain-use efficiencies does not indicate extensive Sahelian desertification. Global Change Biology 4, 359-374.

Rasmussen, K., Foga, B., Madsen, J.E., 2001. Desertification in reverse? Observations from northern Burkina Faso. Global Environmental Change 11, 271-282.

Reij, C., Tappan, G., Belemvire, A., 2005. Changing land management practices and vegetation on the Central Plateau of Burkina Faso (1968-2002). Journal of Arid Environments 63, 642-659.

Rosenzweig, C., Karoly, D., Vicarelli, M., Neofotis, P., Wu, Q., Casassa, G., Menzel, A., Root, T.L., Estrella, N., Seguin, B., Tryjanowski, P., Liu, C., Rawlins, S., Imeson, A., 2008. Attributing physical and biological impacts to anthropogenic climate change. Nature 453, 353-357.

Sankaran, M., Hanan, N.P., Scholes, R.J., Ratnam, J., Augustine, D.J., Cade, B.S., Gignoux, J., Higgins, S.I., Le Roux, X., Ludwig, F., Ardo, J., Banyikwa, F., Bronn, A., Bucini, G., Caylor, K.K., Coughenour, M.B., Diouf, A., Ekaya, W., Feral, C.J. February, E.C., Frost, P.G.H., Hiernaux, P., Hrabar, H., Metzger, K.L., Prins, H.H.T. Ringrose, S., Sea, W., Tews, J., Worden, J., Zambatis, N., 2005. Determinants of woody cover in African savannas. Nature 438, 846-849.

Schlesinger, W.H., Gramenopoulos, N., 1996. Archival photographs show no climateinduced changes in woody vegetation in the Sudan, 1943-1994*. Global Change Biology 2, 137-141.

Seaquist, J.W., Olsson, L., Ardo, J., Eklundh, L., 2006. Broad-scale increase in NPP quantified for the African Sahel, 1982-1999. International Journal of Remote Sensing 27, 5115-5122.

Shanahan, T.M., Overpeck, J.T., Anchukaitis, K.J., Beck, J.W., Cole, J.E., Dettman, D.L., Peck, J.A., Scholz, C.A., King, J.W., 2009. Atlantic forcing of persistent drought in West Africa. Science 324, 377-380.

Trenberth, K.E., Jones, P.D., Ambenje, P., Bojariu, R., Easterling, D., Klein Tank, A. Parker, D., Rahimzadeh, F., Renwick, J.A., Rusticucci, M., Soden, B., Zhai, P., 2007. Observations: surface and atmospheric climate change. In: Solomon, S., Qin, D. Manning, M., Chen, Z., Marquis, M., Averyt, K.B., Tignor, M., Miller, H.L. (Eds.), Climate Change 2007: The Physical Science Basis. Contribution of Working Group I to the Fourth Assessment Report of the Intergovernmental Panel on Climate Change. Cambridge University Press, Cambridge, pp. 235-336.

Tucker, C.J., 1979. Red and photographic infrared linear combinations for monitoring vegetation. Remote Sensing of Environment 8, 127-150.

Tucker, C.J., Pinzon, J., Brown, M., Slayback, D., Pak, E., Mahoney, R., Vermote, E., El Saleous, N., 2005. An extended AVHRR 8-km NDVI dataset compatible with MODIS and SPOT vegetation NDVI data. International Journal of Remote Sensing 26, 4485-4498.

U.S. Centers for Disease Control, 1973. Nutritional Surveillance in Drought Affected Areas of West Africa (Mali, Mauritania, Niger, Upper Volta). U.S. Public Health Service, Atlanta.

Vincke, C., Diedhiou, I., Grouzis, M., 2010. Long term dynamics and structure of woody vegetation in the Ferlo (Senegal). Journal of Arid Environments 74, 268-276.

Wang, G., Eltahir, E.A.B., 2002. Impact of $\mathrm{CO}_{2}$ concentration changes on the biosphere-atmosphere system of West Africa. Global Change Biology 8 1169-1182.

Wezel, A., Lykke, A.M., 2006. Woody vegetation change in Sahelian West Africa: evidence from local knowledge. Environment, Development, and Sustainability 8, 553-567.

Zeng, N., Neelin, J.D., Lau, K.M., Tucker, C.J., 1999. Enhancement of interdecadal climate variability in the Sahel by vegetation interaction. Science 286, 1537-1540.

Zhang, X., Zwiers, F.W., Hegerl, G.C., Lambert, F.H., Gillett, N.P., Solomon, S., Stott, P.A., Nozawa, T., 2007. Detection of human influence on twentieth-century precipitation trends. Nature 448, 461-465. 